\title{
Scientific Background of Dairy Protein Digestibility: A Review
}

\author{
ASHOK KUMAR SHRESTHA* \\ Nutrition and Food Science Program, School of Science and Health, University of Western Sydney, Building M15, \\ Hawkesbury Campus, Sydney, Australia
}

Recent advances have shown that differences in compositional, structural and physical properties of caseins and whey proteins affect their digestion and absorption behavior, hormonal response, satiety effect and other physiological effects. For example, the ingestion of whey protein cause fast, high and transient increase of amino acids 'fast protein', whereas casein induce slower, lower and prolonged increase of 'slow protein' in the gut. Knowledge of, and control over, the rate and nature of digestive breakdown of dairy proteins provides a potential basis for product/process innovation through identifying ingredients and formulations that provide desired nutrient delivery profiles. With this background, the aim of our current review paper is to understand the digestion behavior of various protein-rich milk powders and their potential use in formulation of dairy foods for controlled release of amino acids and energy. Currently available in vitro protein digestibility methods to measure or predict the dairy protein digestibility were also investigated. The author has also presented the preliminary results of ongoing study on in vitro digestion of various commercial proteins powders.

Keywords: In vitro digestion, Caseins, Whey proteins, Processing

\section{Introduction}

Proteins are the most important ingredient present in milk and milk products due to its nutritional significance, role in stability and rheology, allergenicity, biological activities of its bio-peptides and various functional properties. Recent advances in dairy sciences have shown the differences in compositional, structural and physical properties of caseins and whey proteins affect their digestion and absorption behavior in the human gut. There is a keen interest in understanding how protein is digested in the gastrointestinal tract as it has been linked to various physiological conditions. Knowledge of, and control over, the rate and nature of digestive breakdown of dairy proteins provides a potential basis for product/process innovation through identifying ingredients and formulations that provide desired nutrient delivery profiles. For example, designing formulations that lead to sustained but complete uptake of proteins for maximal physiological and/or satiety benefits.

Recent studies have shown the ingestion of whey protein cause fast, high and transient increase of amino acids 'fast protein', whereas casein induce slower, lower and prolonged increase of 'slow protein' in the gut (Boirie et al., 1997; Dangin et al., 2001; Lacroix et al., 2006). Casein clotting in stomach thought to cause slow emptying whereas more soluble whey proteins rapidly pass through to duodenum causing postprandial aminoacidemia (Boirie et al., 1997). This leads to greater post-prandial amino acid concentration (25-50\%) and $\beta$-cell response (insulin, C-peptide, pro-insulin, 12-40\%) for whey and free amino acid meals compared to caseins (Nilsson et al., 2004). Dietary proteins are more satiating per $\mathrm{kJ}$ than carbohydrate and lipids (Anderson et al., 2004). It has been reported that more than 20 peptide hormones present in gut

\footnotetext{
*Corresponding author, E-mail: a.shrestha@uws.edu.au
}

such as cholecystikinin, gastric inhibitory peptide, Glucagon like peptides and regulatory hormones such as regulatory hormones insulin, leptin etc., controlled by central nervous system, regulates the food intake and satiety. The rate of protein digestion not only affect the ability of the body to assimilate amino acids (Crittenden et al., 2009), impacts on insulin regulation (Tessari et al., 2007) that lead to the stimulation of many physiological and metabolic responses known to be involved in food intake regulation (Anderson and Moore, 2004). These events have implication on the design of (dairy) protein/carbohydrate composite products.

\section{Rationale of protein digestibility studies}

The nutritive value of a protein is evaluated by the amino acid profiling. But it is the (degree of) protein digestibility which determines primary availability of peptides and amino acids. The digestibility of a food protein and the bioavailability of peptides or amino acids may be obtained by using rat bioassay (Hsu et al., 1977) which is quite cumbersome. Study of postprandial whole protein metabolism requires human subjects, which involves combining oral and intravenous administration of labeled and unlabelled proteins to measure amino acid kinetics after meal which is an expensive and highly tedious exercise (Boirie et al., 1997; Lacroix et al., 2006). In vitro digestion that mimics the in vivo condition is an option for such studies but it has to be backed up by animal or human digestion studies for full validation. The unique passage of foods into the digestive tract where it is exposed to a series of enzymes, varying rheological conditions, constant absorption of degraded protein molecules, hormonal responses to proteins/amino acids is difficult to reproduce. A parallel study of the rheology of dairy components needs to be carried out to identify factors likely to impact on passage rate through the upper alimentary canal. The protein digestibility 
assay, particularly pepsin digestibility, has been used to determine the relative stability of a protein to the extremes of $\mathrm{pH}$ and pepsin-protease encountered in the mammalian gastric environment. It was used for assessing the nutritional value of protein sources by predicting amino acid bioavailability (Zikakis et al., 1977; Marquez and Lajolo, 1981).

Thermal treatment of milk and milk products at various stages of processing and stabilization is known to affect their nutritional properties (Carbonaro et al., 1997). Both endogenous thermolabile components of milk and milk products can be used as an indicator of heat damage, particularly whey proteins. In vitro digestibility of processed milks (pasteurized, UHT and sterilized) are higher than raw milk (Carbonaro et al., 1997) which is in a way conform that heating of milk and milk production induce the gross changes in protein conformation with subsequent proteolytic cleavage of previously inaccessible sites (Lyster, 1979; Finley, 1985).

The major allergenic proteins of peanut, soybean, egg and milk have been determined in a pepsin digestion assay using simulated gastric fluid (SGF). Generally, the allergens and lectins examined in these experiments were resistant to pepsin digestion whereas the other proteins were more rapidly and completely digested. Cow's milk has one of the highest levels of food allergen and is at the top of all lists of epidemiological data. The human gastrointestinal fluids more rapidly digest nutritionally desirable proteins but most of the food allergens exhibit proteolytic stability. $\beta$-lactoglubulin is one of such potent milk allergens that show a high stability against proteolytic enzyme. Heat treatment slightly increases the pepsin hydrolysis whereas natural fermentation significantly improve the digestibility of $\beta$-lactoglubulin ( $40 \%)$ (Maier et al., 2006). Analysis of cow's milk proteins in infant formula showed the whey proteins, $\beta$-lactoglobulin and $\alpha$-lactalbumen, are entirely resistant to digestion from $\mathrm{pH} 1.5$ to 3, whereas casein showed good digestibility (Sakal et al., 2000). A multi-interlaboratory evaluation showed there is no standard protocol for digestibility of proteins measurement with potential variation in $\mathrm{pH}$, pepsin purity, pepsin to target protein ratio, target protein purity and method of detection (Thomas et al., 2004).

Maillard reaction of milk proteins is known to occur ubiquitously during processing and storage of milk. It is known to improve many techno-functional properties of the milk products. Hiller et al., (2010) showed the post Maillard modification in vitro digestion of sodium caseinate decrease digestibility by $36-55 \%$ whereas increased in the case of whey proteins. It was concluded that sodium caseinate form tightly weaved networks that sterically hindered the proteolysis. On the other hand, partial unfolding of protein structures during Maillard reaction, relating to hydrothermic conditions may facilitate proteolysis of globular whey proteins. It is also suggested that complex sugars like dextrin leads to unfolding of $\beta$-lactoglobulin molecules that making previously inaccessible peptides bond available for enzymatic action.

\section{Literatures on in vitro protein digestibility studies}

There have been several studies on in vitro methods of protein digestibility. Earlier in vitro studies used pepsinpancreatin (Akeson and Stahmann, 1964), enzyme preparation from Streptomyces griseus (Ford and Salter, 1966), papain (Buchanon and Byers, 1969), and papain-trypsin system (Saunder et al., 1973) for protein digestibility studies (as referred by Hsu et al., 1977). Saunder et al. (1973) found that the values obtained by the enzyme system used by Akeson and Stahmann et al., (1964) and Saunder et al., (1973) showed excellent correlation with $\mathrm{R}=0.88$ and 0.91 , respectively. However, papain as a sole enzyme (Buchanan and Byers, 1969) showed poor correlation with in vivo data. Rhinehart (1975) trials with triple enzyme systems also showed good correlation with in vivo studies (as referred by Hsu et al., 1977).

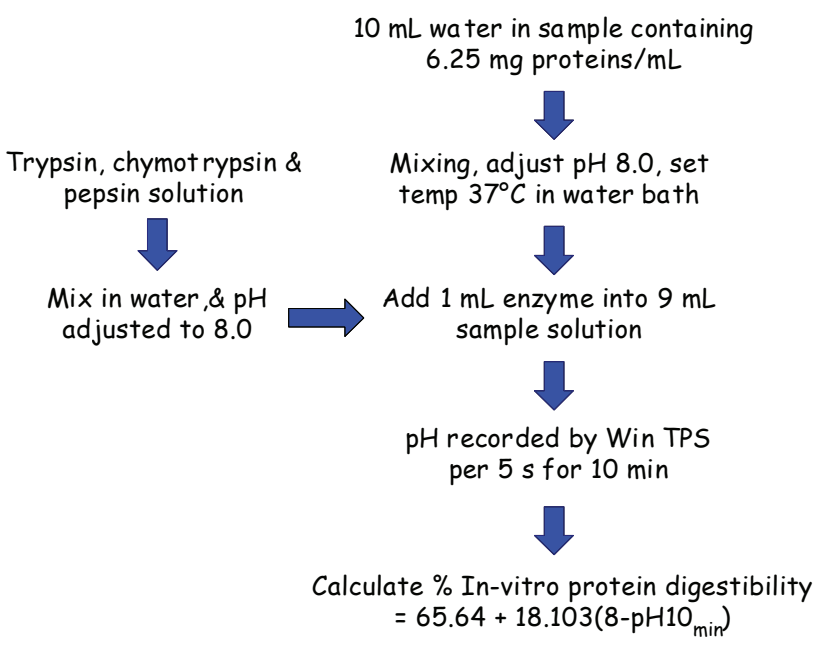

Figure 1. Digestibility protocol for various milk samples

Hsu et al., (1977) developed a less complicated, rapid but reliable in vitro method where porcine pancreatic trypsin, bovine chymotrypsin and intestinal peptidase were added together to protein samples set at $\mathrm{pH} 8.0$ and drop in $\mathrm{pH}$ was measured till $10 \mathrm{~min}$ of digestion (Figure 1). On the other hand, they also measured the in vivo digestibility of the particular protein sample using rat as a subject. An equation was developed by regression analysis, such as $(\%$ digestibility $=210.46-18.10 \mathrm{X}_{1}$, where $\mathrm{X}_{1}$ is the $\mathrm{pH}$ of the test sample after $10 \mathrm{~min}$ ). The method appeared to be equally good for various types of foods including dairy products with high degree of correlation, as shown in the Table 1. Digestibility data from the multi-enzyme treatment of 5 different proteins showed the rate of digestion differ greatly. Casein appeared to be undergoing rapid drop in $\mathrm{pH}, 8.0$ to 6.7 , as compared to its counterpart whey protein, 8.0 to 7.4 , that shows the nature/ 
composition of proteins dictates their rate of digestibility too (Figure 2). It also indicates casein has faster digestion rate as compared to the whey protein. It is one of the highly cited studies in protein digestibility (429 citations).

Bodwell et al., (1980) tested digestibility of six proteins preparation with modified Hsu et al. (1979) method (20 min digestion) and 4 enzyme methods (adding bacterial protease).
These digestibility data were compared with human and rat assays. In general, the digestibility values obtained from these three in vitro studies were not greatly different. For cottage cheese, \% digestibilities were $86.5,92.2$ and $87.1 \%$ for trienzyme, modified tri-enzyme and four enzyme methods, respectively. They concluded the use of in vitro enzyme procedures would only give an approximate estimate of digestibility in humans.

Table 1. In vivo and in vitro measurements of protein digestibility ${ }^{1}$

\begin{tabular}{lccc}
\hline \multicolumn{1}{c}{ Samples } & $\begin{array}{c}\text { In vivo } \\
\text { digestibility }\end{array}$ & $\begin{array}{c}\text { In vitro } \\
\text { digestibility }\end{array}$ & Differences \\
\hline Casein & 90.5 & 89.2 & 1.3 \\
Soy isolate & 89.6 & 88.1 & 1.5 \\
Partially delactosed whey & 73.1 & 76.7 & -3.6 \\
Corn-Milo grain & 72.0 & 73.6 & -1.6 \\
High protein wheat bran flour & 77.5 & 76.9 & 0.6 \\
General wheat flour & 81.9 & 85.7 & -3.8 \\
Non-fat dry milk & 84.7 & 82.5 & 2.2 \\
Corn DPC alcohol washed & 79.2 & 79.4 & -0.2 \\
Extruded puff A & 79.2 & 81.9 & -2.7 \\
Unextruded puff A & 78.0 & 80.3 & -2.3 \\
Extruded puff B & 85.1 & 85.0 & 0.1 \\
Unextruded puff B & 82.9 & 83.6 & -0.7 \\
ANRC casein & 87.6 & 88.1 & -0.5 \\
Blended C bread & 83.0 & 79.6 & 3.4 \\
Blend C ingredients & 84.4 & 85.7 & -1.3 \\
Wheat protein concentrate & 89.9 & 90.4 & -0.5 \\
Yeast protein concentrate & 86.5 & 83.2 & 3.3 \\
Bean protein concentrate & 84.3 & 84.1 & 0.2 \\
Soy concentrate & 87.7 & 87.2 & 0.5 \\
Full lactose whey & 78.6 & 76.5 & 2.1 \\
\hline${ }^{1}$ Hsu $e t$ al., (1977) & & &
\end{tabular}

Parrot et al., (2003) measured the in vitro digestibility of cheese (as water soluble extract and casein) using multiple enzymes to study the effect of digestive enzymes on the biological activity of peptides present in dairy products. Initially acidified cheese sample $(\mathrm{pH} 2)$ was treated with pepsin and incubated for $30 \mathrm{~min}$ and neutralized to stop pepsin activity. Further digestion was performed with trypsin or pancreatin for $4 \mathrm{hr}$, enzyme activaterd and stored at $-20^{\circ} \mathrm{C}$. The extract was analysed for protein content by SDS-PAGE, N-analysis by Kjeldahl method and peptide analysis by RP-HPLC. Results showed the digestion of cheese extract induce an increase in ACE (angiotensin-I converting enzyme, ACE) inhibition in compared to undigested extract. ACE is a dipeptidyl carboxypeptidase which catalyses both the production of the vasoconstrictor angiotensin-II and the inactivation of the vasodilator bradykinin, the inducing hypertensive effects. 


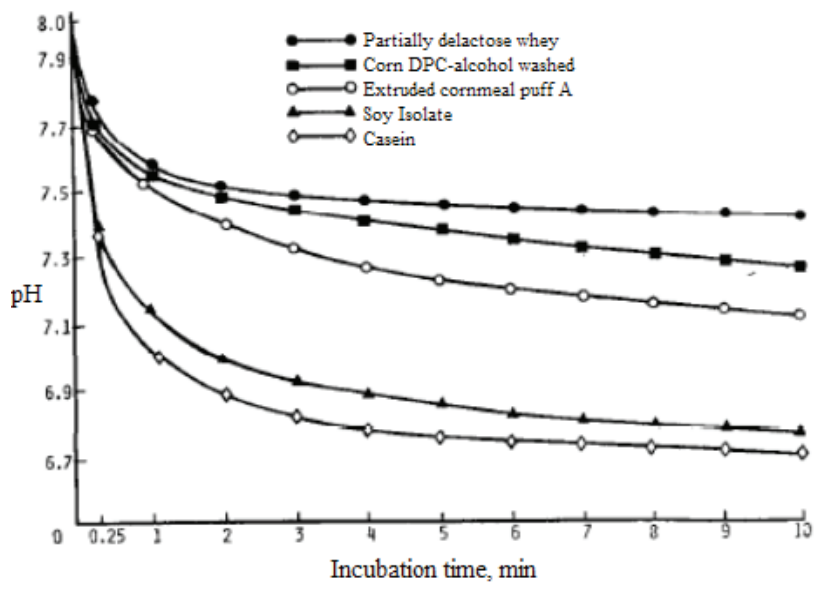

Figure 2. Examples of pH vs time curves obtained by incubation of the protein sources with the multi-enzyme systems (From Hsu et al., 1977)

Measurement of peptic digestibility of cow's milk protein in commercially available infant foods under various $\mathrm{pH}$ conditions showed interesting results (Sakai et al., 2000). Aqueous solutions of infant formula were acidified from 1.5, 2.0, 2.5, 3.0 and 4.0 pH. Dilute $\mathrm{NaCl}$ solution was incorporated in one of the solutions ( $\mathrm{pH} 2.0$ ). Digestion of these extracts was done by porcine pepsin at 30,60 and $120 \mathrm{~min}$ at $37^{\circ} \mathrm{C}$ in reciprocating water bath. The extract were neutralized and subjected to SDS-PAGE and subsequent analysis to determine quantity of protein present. Whey proteins, $\beta$-lactoglobulin and $\alpha$-lactalbumen, were digested at $\mathrm{pH} 1.5$ to 2.5 but almost entirely resistant to peptic digestion at $\mathrm{pH}$ 3.0. Casein had similar digestibility from 1.5 to $3.5 \mathrm{pH}$ but slower at $\mathrm{pH}$ 4.0. Inclusion of $\mathrm{NaCl}$ in did not affect the casein digestibility but lowered digestibility of whey proteins.

In vitro digestion assays have been frequently used to analyze the resistance of pepsinolysis of certain proteins which are potentially allergenic. This has led to a number of in vitro studies dedicated to measure the resistance of allergens, whey proteins (particularly $\beta$-lactoglobulin), to pepsin hydrolysis (Carbonaro et al., 1997; Kitabatake and Kinekawa, 1998; Mouecoucou et al., 2004; Maier et al., 2006; Roufik et al., 2007). The methods used for these vitro studies, however, differed with investigators.

Carbonaro et al., (1997) used triple enzyme method of Bodwell et al., (1980) to measure \%digestibility of 18 variously heat-treated milk samples. They further analyzed the disulfide reactivity and amino acid profiles to come at conclusion that thermal treatment of whey proteins make it less digestible (in heat treated milk and milk products). Maier et al., (2006) used peptic digestion of $\beta$-lactoglobulin ( $\beta \mathrm{LG})$ containing milk samples and capillary zone electrophoresis (CZE) to study the proteolytic resistance (allergenic proteins). The acidified sample solution $(\mathrm{pH} 1.5)$ were incubated with pepsin in $1: 20$ ratio at $37^{\circ} \mathrm{C}$ and incubated at different time intervals. Aliquots were taken at different intervals to analyze the proteolytic degradation of $\beta$-lactoglobulin level at different time intervals. $\beta \mathrm{LG}$ extract showed minimal digestibility ( $<2 \%$ in $2 \mathrm{~h}$ ) whereas raw and pasteurized milks were digested up to $45 \%$ in $2 \mathrm{~h}$ ). Mouecoucou et al., (2004) studied interactions between $\beta \mathrm{LG}$ and polysaccharides by in vitro gastric and pancreatic hydrolysis in dialysis bags followed by measurement of nitrogen release and protein quality by SDS-PAGE. Results showed that $\beta$ LG was almost resistant to pepsin digestion and the plant hydrocolloids inhibited significantly $\beta \mathrm{LG}$ digestibility as determined by using dialysis bag with a $1000 \mathrm{MW}$ cutoff. Roufik et al., (2007) measured the digestibility of antihypertensive peptides from $\beta$-lactoglobulin (lactokinins or $\beta \mathrm{LG}$ ) and bound complex $\beta \mathrm{LG}$ and $\beta$-lactoglobulin variant A ( $\beta$-LGA) using two step digestion methods similar to Mouecoucou et al., (2004) minus dialysis bag. The pepsin digested substrate was withdrawn at various intervals and immediate raised to $\mathrm{pH} 8.0$ and digested with trypsin, chymotrypsin or pancreatin. Reverse Phase HPLC was used to measure the degree of hydrolysis of these individual peptides or their complexes. Digestibility of $\beta$-LGA and of the complexes determined using pepsin, trypsin, pancreatin, pepsin/trypsin, and pepsin/pancreatin were similar, whereas chymotrypsin and pepsin/chymotrypsin digested the complexes more slowly.

\section{Dairy protein digestibility-current perspective}

Literature survey suggests various factors, from sample preparation to analysis of digesta, might have impact on the digestibility study of milk proteins. For example, allergenicity study of milk protein/peptides warrants digestion of the given protein with pepsin in the simulated stomach condition whereas metabolic study of a given protein may warrant simulated peptic as well as simulated gut conditions. More sophisticated techniques are needed if detail identification of peptides and amino acids are to be analyzed. It is understood that simulation of digestion conditions (as in various parts of alimentary canal) during in vitro digestion of proteins is critical. The $\mathrm{pH}$ of the substrate (or substrate/enzyme); rheological properties of the mixture and local condition; mixing such as peristalsis, extending/contracting motion, gravity; secretion of several enzymes, bile, mucus etc. can have significant effect on digestion of the protein.

Our previous study on the digestibility of processed as well as granular (raw) starch suggests bulk protein digestibility may be more related to the physical forms such as size of granules, porosity, crystallinity etc. of the ingredient along with its molecular composition (Shrestha et al., 2010; Dhital et al., 2010). For example, there is greater resistance to pepsin digestion for $\beta$-lactoglobulin due to numerous disulfide bonds that stabilize structure, but the role of compact globular structure that hinders the access of proteolytic enzymes to the vulnerable protein sites (Carbonaro et al., 1997) is equally important. The major protein in the bovine milk, casein, is 
well digested because of its poor secondary structure with and more open structure which is vulnerable to proteolysis (Bodwell et al., 1980). It is hypothesized that rates and extents of digestion of dairy ingredients (and hence biological effects such as protein accretion and satiety) can be controlled by appropriate selection of raw materials, processing and formulation.

We recently studied the in vitro digestion behavior of skim milk powders (SMP) (low heat and medium heat SMP), caseins (casein micelle and sodium caseinate) and whey proteins (concentrate and isolate). These powders were dissolved in water and left at room temperature for few minutes. Each sample solutions were separately heated for $100^{\circ} \mathrm{C}$ for $1-2 \mathrm{~s}$ (Boiling); $66^{\circ} \mathrm{C}$ for $30 \mathrm{~min}$ (pasteurization); $72^{\circ} \mathrm{C}$ for $15 \mathrm{~s}$ (high temperature short time, HTST) and a control (room temperature). These samples were analyzed for protein digestibility characteristics following Hsu et al. (1977) (Figure 3). The equation developed by Hsu et al., (1977) as previously described $\left[\%\right.$ Digestibility $=210.46-18.10 \mathrm{X}_{1}$, where $\mathrm{X}_{1}$ is the $\mathrm{pH}$ of the test sample after 10 $\mathrm{min}$ ] was used for the calculation of in vitro percentage digestibility (IVPD).

The process of protein digestion leads to hydrolysis of polypeptides that eventually lead to formation of smaller peptides and free amino acids. Release of amino acids during digestion is accompanied by a drop in $\mathrm{pH}$ of the test solution. The rate of $\mathrm{pH}$ drop with time is the function of protein digestibility. Figure 3 showed the skim milk powders had the slowest digestibility trend among the 4 milk ingredients, in all processing conditions. Digestibility curves indicate a mixed result for whey proteins and caseins e.g., casein had faster digestion at room temperature whereas whey proteins had faster digestion during pasteurization (Figure 3). These findings against the common norms that caseins are 'slow digesting' and whey proteins are 'fast digesting'. Two major factors that might have resulted in this opposite trends are: The samples used in the current study were commercially produced. These were exposed to rigorous physical and chemical treatments. Their native structures likely to have significantly altered that potentially affect the enzyme hydrolysis significantly. Carbonaro et al., (1997) also reported that thermal treatment of whey proteins make it less digestible.

In vivo digestion protocol involves exposure of proteins to very low $\mathrm{pH}$ (gastric $\mathrm{pH} \sim 2.2$ ) and pepsin in stomach. This leads to breakage of the peptide bond between Phenylalanine (at 105) and Methionine (106), micellar flocculation, gel formation and loss of solubility. This event leads to less access of enzymes (trypsin, chymotrypsin and peptidase) to
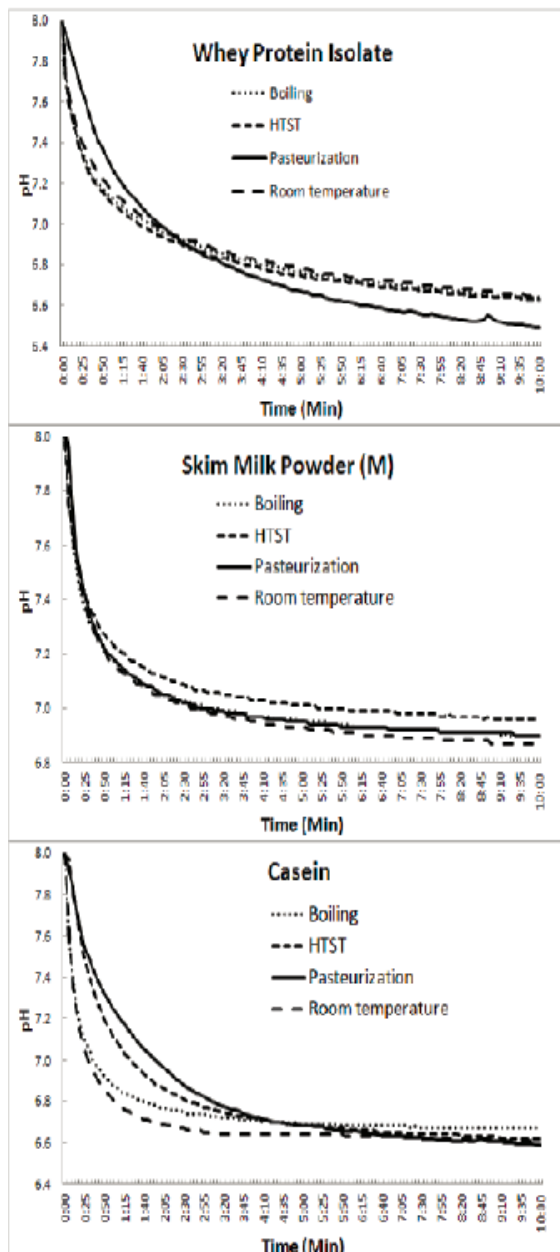

Time (Min)
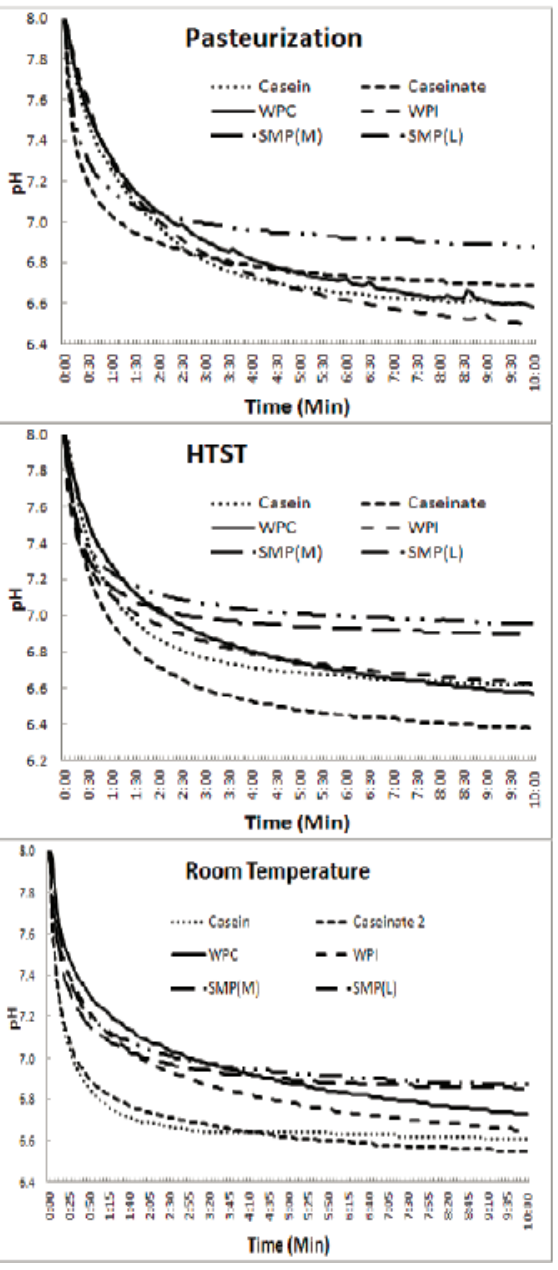

me (Min)

Figure 3. In vitro protein digestibilities of various dairy proteins powders under varying processing conditions.

the substrate, slowing digesting significantly. On the other hand, soluble fraction of proteins such as whey proteins are less affected by low $\mathrm{pH}$ and the native structure remain more or less unchanged in gastric condition. The smaller whey proteins more likely to be digested by proteolytic enzymes than 'precipitated casein'. Current in vitro protocol bypassed the gastric digestion step and only simulates the intestinal digestion. It is most likely to have influenced faster digestion rate of casein as compared to whey proteins. Bodwell et al., (1980) has also previously reported that casein is well digested by proteolytic enzymes because of its poor secondary structure and more open structure.

The in vitro protein digestibility (IVPD) data (Table 2) also 
showed the SMPs have the lowest digestibility as compared to whey proteins and caseins. It appears that previous heat treatment $\left(\sim 85^{\circ} \mathrm{C}\right)$, vacuum concentration and spray drying of skimmed milk during manufacturing stages may have altered the protein configuration lowering the protein digestibility. IVPD data also showed that there is a lesser variation in digestibility curves of SMPs under different processing conditions, as compared to others. Table 2 also showed whey proteins had only slightly higher IVPD value as compared to caseins. HTST treatment of sodium caseinate appears to increase IVPD value significantly. It indicates solubilized sodium salts of whey protein tend to be more digestible than casein when boiled. We found the current in vitro digestion method is less complicated, short, rapid, and reported to be reliable method of protein digestibility. However, it is not known if this method can differentiate the digestibility behaviour of proteins from various milk sources, as it is very basic mimicking of in vivo digestion process and lacking in gastric digestion stage.

For any promising leads, in vitro digestion results would need to be backed up by animal or human digestion studies for full validation. The two factors that determine in vivo digestion rates are the intrinsic digestion rates (as predictable from in vitro studies) and the rate of passage, which is primarily a

Table 2. In vitro protein digestibility (IVPD) values of various milk powders

\begin{tabular}{lccccc}
\hline Protein types & \%Protein & & \multicolumn{5}{c}{ \%In vitro protein digestibility (IVPD) } \\
& & Boiling & HTST & Pasteurization & Room Temperature \\
\hline SMP-Low heat & 33.6 & 85.8 & 85.5 & 84.7 & 85.5 \\
SMP-Med heat & 33.3 & 85.1 & 83.9 & 86.2 & 86.3 \\
WP Concentrate & 76.5 & 90.3 & 91.7 & 91.2 & 89.6 \\
WP Isolate & 90.2 & 90.6 & 90.8 & 92.8 & 89.9 \\
Casein & 86.9 & 89.8 & 90.7 & 89.9 & 90.5 \\
Na-caseinate & 90.2 & 91.2 & 94.7 & 90.0 & 91.1 \\
\hline
\end{tabular}

function of rheological properties under the local conditions operating through the digestive tract. There is a transformation from protein in structured food into masticated and bolus formation in the mouth which is suddenly exposed to gastric juice of stomach ( $\mathrm{pH} 1.5$ to 3.0) and sudden aggregation. Biosurfactant such as phosphatidylcholine may react with protein to change its structure. In many cases, proteins in food exist as emulsion; in such case proteins/peptides is displaced by phospholipids. Emulsion destabilization takes place in stomach leading to flocculation, coalescence and phase separation. The protein aggregates exposed to shearing or mixing when it exit from pyloric sphincter to the duodenum. In small intestine, protein is exposed to a range of hydrolytic enzymes and range of biosurfactants such as bile acids and phospholipids. Thus a parallel study of the rheology of dairy components would need to be carried out to identify factors likely to impact on passage rate.

\section{Conclusions}

Dairy protein is the major source dietary proteins for human kind. The factors affecting the rate of protein digestion from dairy products largely affect the protein utilization and subsequent effect on the human health such as weight management, muscle health, diabetes control etc. Based on digestibility, caseins are classified as 'slow' whereas, whey proteins as 'fast' digesting proteins. Protein molecules are highly sensitive to processing conditions such as heat, acidity/alkalinity, enzymes, pressure etc., that directly or indirectly affect its molecular conformation, digestibility and bioavailability peptides and amino acids. This review showed that digestibility study of the dairy proteins are affected by a number of factors such as type dairy proteins (caseins $v s$ whey proteins), physical state of dairy foods, method of analysis e.g., types of enzymes used, steps of digestion, incubation time, etc. and also about various analytic methods to characterize the digested proteins.

\section{References}

Akeson W. R. and Stahmann M. A. (1964). A pepsinpancreatin digestibility index of protein quality. $J$. of Nutri., 83: 251-255. 
Anderson G. H. and Moore S. E. (2004). Dietary proteins in the regulation of food intake and body weights in humans. J. of Nutri., 34: 974S-979S.

Bodwell C. E., Satterlee and Hackler L. R. (1980). Protein digestibility of the same protein preparations by human and rat assays and by in vitro enzymic digestion methods. Am. J. of Clinincal Nutri., 33: 677-686.

Boirie Y., Dangin M., Gachon, Vasson M. P., Maubois J. L. and Bernard, Beaufrere B. (1997). Slow and fast dietary proteins differently modulate postprandial protein accretion. Proceeding of National Academy of Science, USA 94, 14930-14935.

Buchanan, R. A. (1969). In vivo and in vitro methods of measuring nutritive value of leaf protein concentrates. British Journal of Nutrition, 23: 533-535.

Carbonaro M. Cappelloni M. Sabbadini S. and Carnovalem K. (1997). Disulfide Reactivity and In Vitro Protein Digestibility of Different Thermal-Treated Milk Samples and Whey Proteins. J. of Agri. and Food Chem., 45: 95-100.

Crittenden R., Buckley J., Cameron-Smith D., Brown A. and Thomas S., Davey S. and Hopman P. (2009) Functional dairy protein supplements for elite athletes Australian J. of Dairy Tech., 64: 133-137.

Dangin M., Boirie Y., Garcia-Rodenas C., Gachon P., Fauquaant J., Callier P., Balle'vre O. and Beaufre'Re B. (2001). The digestion rate of protein is an independent regulating factor of postprandial protein retention. American J. of Physiology Endocrinology Metabolism, 280: 340-348.

Dhital S., Shrestha A. K. and Gidley M. J. (2010). Relationship between granule size and in vitro digestibility of maize and potato starches. Carbohydrate Polymers. 82: $480-488$.

Finley J. W. (1985). Environmental Effects on Protein Quality. In: Chemical Changes in Food During Processing; Richardson, T., Finley, J. W., Eds.; AVI: Westport, CT, 1985; pp. 443- 482.

Ford J. E. and Salter D. N. (1966). Analysis of enzymatically digested food proteins by Sephadex-gel filtration. British Journal of Nutrition 20, 843-847.

Hiller B. and Lorenzen P. C. (2010). Functional properties of milk proteins as affected by Maillard reaction induced oligomerisation. Food Res. International., 43: 1155-1166.

Hsu H. W., Vava D. L., Satterlee L. D. and Miller G. A. (1977). A multienzyme technique for estimating protein digestibility. J. of Food Sci., 42 (5): 1269-1273.

Kitabatake N. and Kinekawa Y-I (1998). Digestibility of bovine milk, whey protein and $\beta$-lactoglobulin in vitro and in vivo. J. of Agri. and Food Chem., 46: 4917-4923.

Lacroix M., Bos C., Léonil J., Airinei G., Luengo C., Daré S., Benamouzig R.,

Fouillet H., Fauquant J., Tomé T. and Gaudichon, (2006). Compared with casein or total milk protein, digestion of milk soluble proteins is too rapid to sustain the anabolic postprandial amino acid requirement. American J. of Clinical Nutri., 84: 1070-1079.

Lyster R. L. J. (1979). Milk and Dairy Products. In: Effects of Heating on Foodstuffs; Priestley, R. J., Ed.; Applied Science: London, pp. 353-372.

Maier I., Okun V. M., Pittner F. and Lindner W. (2006). Changes in peptic digestibility of bovine $\beta$-lactoglobulin as a result of food processing studied by capillary electrophoresis and immunochemical methods. $J$. of Chrom., 841: 160-167

Marquez U. M. L., Lajolo F. M. (1981). Composition and digestibility of albumin, globulins and glutelins from phaseolus vulgaris. J. of Agri. and Food Chem., 29: 1068-1074.

Mouecoucou J., Villaume C., Sanchez C. and Mejean L. (2004). B-lactoglobulin/ polysacch- aride interactions during in vitro gastric and pancreatin hydrolysis assessed in dialysis bags of different molecular weight cut-offs. Biochimica et Biophysica Acta, 1670: 105112.

Nilsson M., Stenberg M., Frid A. H., Holst J. J. and Bjorck I. M. (2004). Glycemia and insulinemia in healthy subjects after lactose-equivalent meals of milk and other food proteins: the role of plasma amino acids and incretins. American Journal of Clinical Nutrition, 80, 1246-1253.

Parrot S., Degraeve, Celine C. and Martial-Gros A. (2003). In vitro study on digestion of peptides in Emmental cheese: Analytical evaluation and influence on angiotensin I converting enzyme inhibitory peptides. Nahrung, 47 (2): 87 - 94.

Rhinehart D. (1975). A nutritional characterization of the distiller's grain protein concentrates. MS thesis, Univiversity of Nebraska, Lincoln, N.E.

Roufik S., Gauthier S. F. and Turgeon S. L. (2007). Physicochemical characterization: and in vitro digestibility of $\beta$-lactoglobulin/ $\beta$-LG f142-148 complexes. Inter. Dairy J., 17: 471-480.

Sakai K., Kenji Yoshino K., Satter M. A., Ota F., Nii Y., Fukuta K., Ueda N., Shimizu Y. and Yamamato S. (2000). Effects of $\mathrm{pH}$ Variation and $\mathrm{NaCl}$ on in vitro digestibility of cow's milk proteins in commercially available infant formulas. J. of Nutri. Sci. and Vitaminology, 46: 325-328. 
Saunders R. M., Connor M., A., Booth A. N., Bickoff E. M. and Kohler. G. O. (1973). Measurement of digestibility' of alfalfa concentrates by in vivo and in vitro methods. J. of Nutri., 103: 530-534.

Shrestha A. K., Ng C. S., Lopez-Rubio A., Blazek J., Gilbert E. P. and Gidley M. J. (2010). Enzyme resistance and structural organization in extruded high amylose maize starch. Carbohydrate Polymer, 80: 699-710.

Tessari P., Kiwauka E., Cristini M., Zaramella M., Enslen M., Zurlo C. and Garcia-Rodenas C. (2007) Slow versus fast proteins in the stimulation of beta-cell response and the activation of the entero-insular axis in type 2 diabetes. Diabetes Metabolism Res. Review, 23: 378-385.
Thomas K., Aalbers M., Bannon G. A., Bartels M., Dearman R. J., Esdaile D. J., Fu T. J., Glatt C. M., Hadfield N., Hatzos C., Hefle S. L., Heylings J., R., Goodman R.E., Henry C., Herouet, Holsapple M., Ladics G. S., LandryT. D., MacIntosh S. C., Rice E. A., Privalle L. S., Steiner H. Y., Teshima R., van Ree R., Woolhiser M. and Zawodny J. (2004). A multi-laboratory evaluation of a common in vitro pepsin digestion assay protocol used in assessing the safety of novel proteins. Regulatory Toxicology and Pharmacology, 39: 87-98.

Zikakis J. P., Rzucidlo S. J. and Biasotto N. O. (1977). Persistence of bovine milk xanthine oxidase activity after gastric digestion in vivo and in vitro. J. of Dairy Sci., 60: 533-541. 